\title{
Indentation testing of thin titanium coatings sprayed with cold gas
}

Keywords:

thermal spraying;

coating;

nanohardness

\begin{abstract}
Material hardness is one of the basic parameters characterizing the properties of matter. In the nanohardness studies, the intendant's deformation can not be neglected. Assuming the proportionality of the intender's deformation to the hardness of the material being tested, a relative hardness measurement was used in the work. Hardness measurement was carried out for fused silica, which was a reference sample. With the same nanotesting parameters, a nanoscale measurement was carried out for two samples.
\end{abstract}

Introduction

One of the basic physical properties of solids is their hardness. Hardness understood as the effect of the material's influence on another material made it possible to create many research methods. Hardness tests are among the most diverse. The first estimation of hardness and its measurement have been carried out many decades ago [1]. One of the methods estimating hardness is the F. Mohs method [2]. It defines the resistance of materials to abrasion or scratching. In other methods, diamond cones or a steel ball were used as indenters. The choice of the indenter was determined by the range of applied forces and the type of material tested [3,4]. Research methods were most often associated with the appropriate type of materials to create different measurement scales $[3,4]$.

When the technology of thin layers (a few micrometers) appeared, the hardness measurement methods mentioned above turned out to be insufficient. There was a need to carry out measurements using forces from a few to several dozen $\mathrm{mN}$. These requirements are guaranteed by nanotesters and enable, for example, the ability to analyze the "load curve", "unload curve". An important issue when it comes to measuring hardness with forces of several to several dozen $\mathrm{mN}$ is to take into account the indenters deformation and the plasticity of the substrate. This issue was analyzed by W.C. Oliver and G.M. Pharr $[5,6]$.

The most frequently used indenters are indenters with geometry of: Berkovich, Vickers. Cube, Spherical $[7,8]$. Modern nanotesters allow an in-depth analysis of the material's reaction to the deforming force.

\section{Experiment}

Hardness tests were carried out on the cross-section for two samples. The WC-12Co sample was made of a powder with granulation of 15 to $45 \mu \mathrm{m}$ (Infralloy S7412). The next coating was made on the basis of $\mathrm{Ti}$ powder, the grains of which were characterized by aspheric shape and a size of $15 \div 60 \mu \mathrm{m}$. The samples were made using Cold Spray technology. The $\mathrm{SiO}_{2}$ (fused silica) sample was used as a calibration material. The chemical composition of powders and coatings was analyzed using scanning microscopes - JSM5400 with ISIS 300 Oxford (EDS) microprobe and FEI Nova NanoSEM 200. The Nanovea's nanotester with an indenter of Berkovich's symmetry was used to analyze the nanohardness of the obtained coating.

\section{Results and discussion of the results}

The classic nanometer hardness measurement tests use the shape of the load-unload curve obtained during the analysis of the movement of the indenter pressed into the material, as well as the tracking of the indenter's movement when it is being removed from the load [6,9]. The most important points of the analysis are the maximum depth to which the indenter is pressed and the maximum force acting on the indenter. The load curve reflects a change in the position of the indenter for a constant rate of force increase over time (e.g. $160 \mathrm{mN} / \mathrm{min}$ ). After reaching the planned value of $80 \mathrm{mN}$ force, the reverse process begins. The indenter has a decreasing

dr Medard Makrenek; dr hab. inż. Wojciech Żórawski, prof. PŚk - Kielce University of Technology, Poland

Corresponding author: fizmm@tu.kielce.pl 
force at the same rate as when creating the load curve. Figure 1 shows an example of a change in the force acting on an indenter as well as its position in a function of time.

The hardness measurement uses the achieved depth value and force used to determine the hardness:

$$
H=\frac{P}{A}
$$

where:

$P$ - maximum force used,

A - surface of the Berkovich's side indenter imprinted with the applied $F$ force.

a)

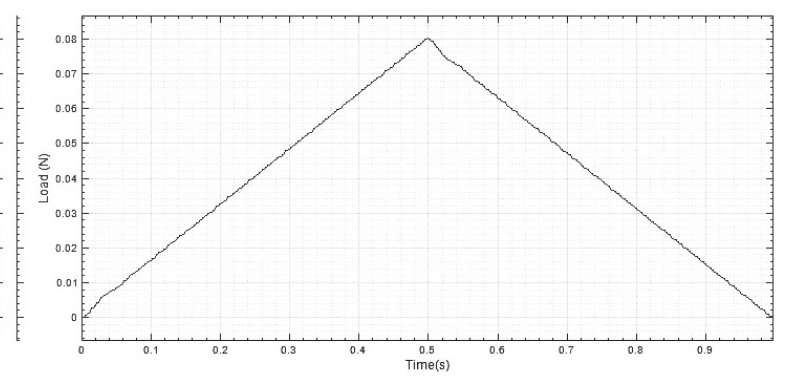

b)

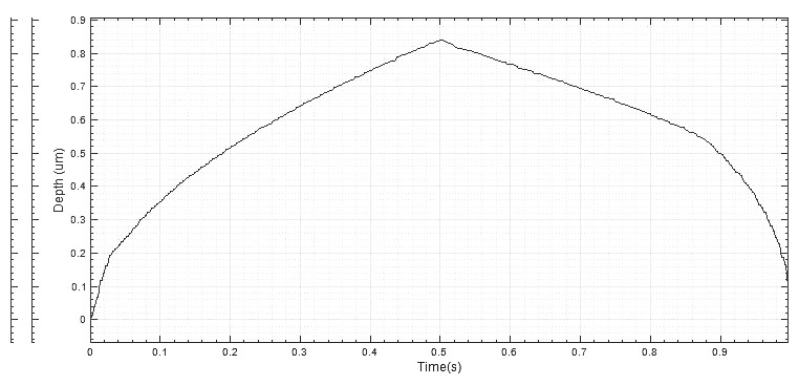

Fig. 1. a) change of the indenter control force as a function of time, b) change of the position of the indenter as a function of time

In the case of materials with a homogeneous structure, it is sufficient to use the force allowing the indenter to exceed the surface layers. In this case, it is a force of about $1 \mathrm{mN}$. Its value results from the analysis of Figure $1 \mathrm{~b}$, which shows a gradual change in the tilt of the curve after approx. 0.02 seconds from the start of the measurement. The initial part of this chart was analyzed for several materials, including $\mathrm{SiO}_{2}$ silica. In each case, the effect of increasing the tilt in the initial phase of nanohardness measurement is observed. A similar effect was observed in the work of e.g. Bandyopadhyay et al. [10]. The following figure 2 is the equivalent of figure 1, but as a function of indenter's travel. The horizontal axis has been scaled so that it is proportional to the imprinted surface. The indenter imprints surfaces in a material proportional to $\mathrm{h} 2$, where $\mathrm{h}$ is the maximum penetration depth of the Berkovich's indenter. Rescaling of the axes' abscissa enables the presentation of data from the picture as the straight line shown in Figure $2 b$.

Similar to W.C. Oliver, the curve from Figure $2 a$ can be matched with a curve that is described by the equation:

$$
P=a\left(h-h_{n}\right)^{m}
$$

where:

$\mathrm{a}, \mathrm{h}_{\mathrm{n}}, \mathrm{m}$ - matching factors, $\mathrm{h}$ function argument, in this situation responsible for the depth of pressing of the Berkovich's indenter.

When the degree of match is not satisfactory it can mean the heterogeneity of the material being tested. In this case, several curves should be matched to the load curve. Figure $2 b$ presents proposals for rescaling the axes' abscissa
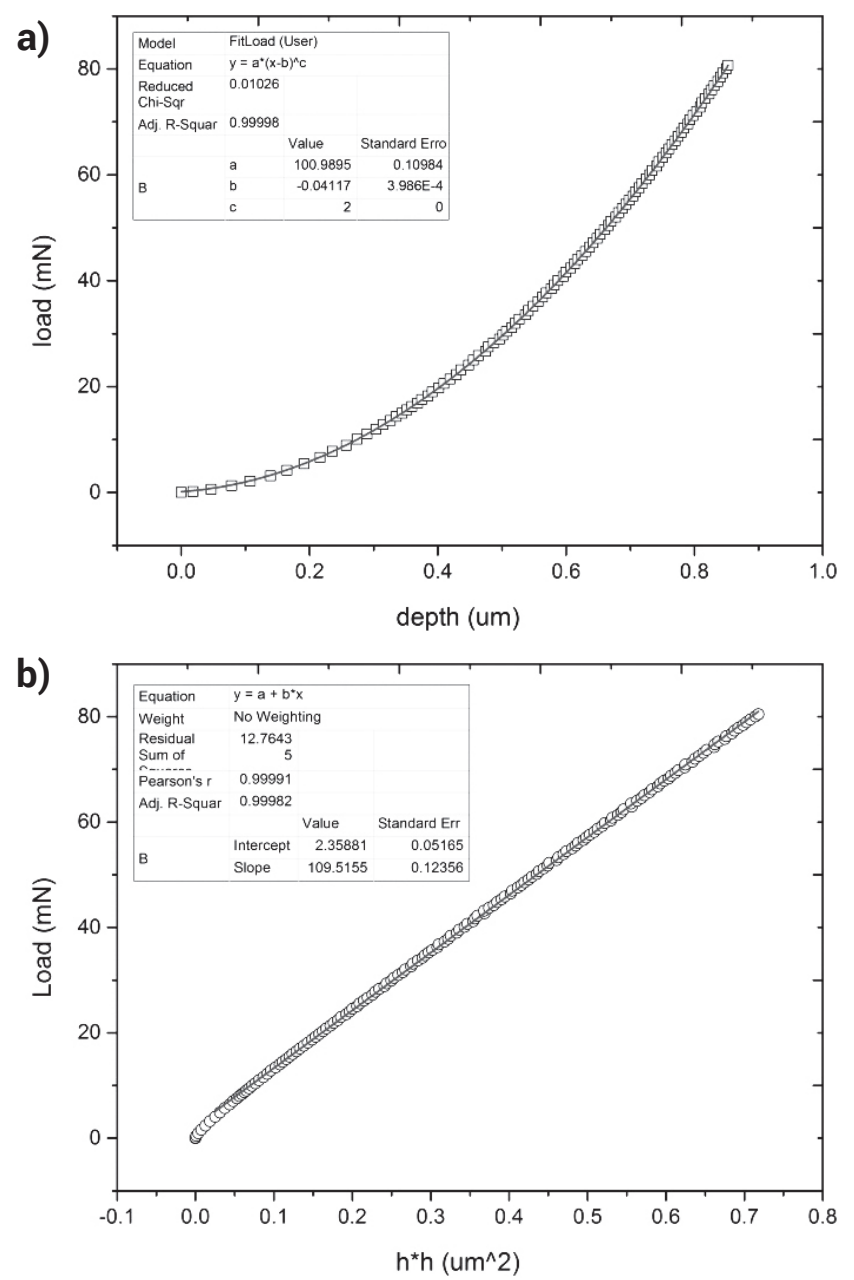

Fig. 2. a) load curve obtained for fused silica along with curve fitting parameters

so that it presents the square of the indenter's displacement $\left(\mathrm{h}^{2}\right)$. In this situation, you can write:

$$
\mathrm{F}=\mathrm{d}+\mathrm{ah}
$$

where:

a - tilt of the straight line.

Direct calculation of hardness from the tilt coefficient of the straight line is not unambiguous. The proportion of the imprinted surface calculated as $24.56 \cdot \mathrm{h}_{\max }{ }^{2}$ does not always give the right results. Using the nanotester it is necessary to take into account the indenter's deformation $[6,7]$. For the calculation of hardness, it seems beneficial to use the relativity of measurements. In the present study, a sample of $\mathrm{SiO}_{2}$ was used as a calibration sample. Assume that the calculated tilt of the line shown in Figure $2 \mathrm{~b}$ for $\mathrm{SiO}_{2}$ reflects the hardness. The proportion of the line tilt for the tested material to the tilt of the standard reference sample will correspond to the ratio between the hardness of the reference sample and the hardness of the tested material. Thus, if the directional coefficient for fused silica is equal to 109 (the coefficient is influenced by the tester parameters) and its table hardness value is equal to $9.4 \pm 0.4 \mathrm{GPa}$, the coefficient of the tested material should be proportional.

$$
h_{E}=h_{F S} \frac{a_{E}}{a_{F S}}
$$

where:

$\mathrm{h}_{\mathrm{E}}-$ searched for hardness,

$\mathrm{h}_{\mathrm{FS}}$ - hardness of the standard, e.g. fused silica,

$\mathrm{a}_{\mathrm{FS}}$ - directional coefficient obtained for the standard, 
$a_{E}$ - directional coefficient of the straight line obtained for the tested sample.

The results obtained are summarized in the following table I. The second column contains results obtained in direct hardness measurements. The fourth column contains the values calculated on the basis of equation 4 .
Table I. Comparison of the determined hardness values in real measurements with the values calculated from equation no. 4

\begin{tabular}{|c|c|c|c|}
\hline Sample & $\begin{array}{c}\text { Hardness } \\
{[\mathrm{GPa}]}\end{array}$ & $\begin{array}{c}\text { Estimated a } \\
\text { coefficient }\end{array}$ & $\begin{array}{c}\text { Estimated hardness } \\
{[\mathrm{GPa}] \text { (pattern 4) }}\end{array}$ \\
\hline Fused silica & $9.4 \pm 0.4$ & $109.52 \pm 0.12$ & - \\
\hline $\mathrm{Ti}$ & $4.39 \pm 0.37$ & $56.17 \pm 2.86$ & $4.93 \pm 2.16$ \\
\hline WC-12Co & $21.5 \pm 1.05$ & $239.37 \pm 1.23$ & $20.6 \pm 0.11$ \\
\hline
\end{tabular}

\section{Conclusions}

The comparison of the tilt coefficient of the straight line illustrating a change in the force used in a square function of the indenter's displacement was made. On the basis of the ratio between the straight-line coefficients (pushing force in a square function of the indenter's displacement), the hardness was estimated for the reference sample and the test sample. Table I presents the hardness values obtained from direct measurements and compared with the values obtained by the proportional method. Discrepancies in results can be caused by porosity and heterogeneity of the sample both in chemical and physical terms. If the points are arranged along a straight line with a different inclination, this may indicate a change in hardness [8].

Work financed from the NCBiR's funds for education as part of the Innolot program „Badania technologii przyrostowych i procesów hybrydyzacji obróbki dla potrzeb rozwoju innowacyjnej produkcji lotniczej”.

\section{References}

[1] S. Błażewski, J. Mikoszewski, Pomiary twardości metali, WNT, Warszawa (1981).

[2] D. Tabo, Proc. Phys. Soc. B (1954), 67, 249.

[3] W.F. Smith, J. Hashem, Foundations of Material Science and Engineering, McGraw-Hill (2001).

[4] L. Dobrzański, Metaloznawstwo i obróbka cieplna stopów metali, Wydawnictwo Politechniki Śląskiej, Gliwice (1993).

[5] W.C. Oliver, G.M. Pharr, An improved technique for determining hardness and elastic modulus using load and displacement sensing indentation experiments, Journal of Materials Research (1992), vol. 7, 1564-1583, .

[6] W.D. Nix, H. Gao, Indentation size effects in crystalline materials: A law for strain gradient plasticity, Journal of the Mechanics and Physics of Solids (1998), vol. 46(3), 411-425.

[7] J.-H. Ahn, D. Kwon, Microchemical estimation of composite hardness using nanoindentation technigue for thin - film coated system, Materials Science ang Engineering A (2000), vol. 285, 172-178.
[8] M. Kot, Analiza właściwości mechanicznych układów powłoka-podłoże przy użyciu metody indentacji z wykorzystaniem wgłębników o różnej geometrii, Tribologia: teoria i praktyka, Polskie Towarzystwo Tribologiczne, Instytut Technologii Eksploatacji - Państwowy Instytut Badawczy (2011), 42, nr 2, 47-60.

[9] W. Żórawski, A. Góral, M. Makrenek, S. Zimowski, Ttribological properties of plasma sprayed Al2O3-13TiO2 nanostructured coatings, Tribologia (2017), Tom: 2, 157-166.

[10] P.P. Bandyopadhyay, D. Chicot, B. Venkateshwarlu, V. Racherla, X. Decoopman, J. Lesage, Mechanical properties of conventional and nanostructured plasma sprayed alumina coatings, Mechanics of Materials 53 (2012), 61-71.

[11] W.C. Oliver et al., Measurement of hardness and elastic modulus by instrumented indentation: Advances in understanding and refinements to methodology , J. Mater. Res. (2004), vol. 19(1). 